\title{
THE EFFECT OF USING GROUP INVESTIGATION METHODS, INQUIRY AND LEARNING STYLE ON LEARNING OUTCOMES
}

\author{
Achmad Noor Fatirul and Djoko Adi Walujo \\ Faculty / Study Program: Graduate School / Educational Technology \\ PGRI Adi Buana University Surabaya, East Java, Indonesia
}

\begin{abstract}
This study aims to distinguish 2 learning methods, namely investigative learning methods that will be compared with inquiry learning methods. Both methods apply a learning model that prioritizes groups and makes discoveries.

The results of hypothesis testing concluded that the group learning method has higher learning outcomes than the inquiry learning method, while students who have different learning outcomes are dominated by students who have kinesthetic, then visual and auditory learning styles. The third conclusion is obtained that the learning methods and learning styles have a positive interaction on the achievement of student learning outcomes.
\end{abstract}

\section{KEYWORDS}

Group Investigation, Inquiry, Learning Styles, Learning Outcomes

\section{Preliminary}

Entering the 21st century, the state of Indonesia's human resources is very uncompetitive. According to the UNDP version of the Human Development Report, the ranking of the Human Development Index or the quality of Indonesia's human resources is 112, far below the Philippines (85), Thailand (74), Malaysia (58), Brunei Darussalam (31), and Singapore (28). Meanwhile, the Third Matemathics and Science Study (TIMSS), an institution that measures education outcomes in the world, reports that the ability of our high school students is 34th out of 38 countries, while the ability of science is 32 nd out of 38. country (Nurhadi, et al. 2004). Meanwhile, the International Educational Achievement (IEA) organization reports that the ability of senior high school students in Indonesia is only 40th out of 42 countries.

This shows that the scientific ability of high school students in Indonesia is still far below the average scientific ability of other countries in the world. It is necessary to improve the education system and process to improve student learning outcomes. So far, the science learning process is still mechanistic (tends to be theoretical, teacher centered, transferring). In Indonesia the learning process, a teacher never connects material with real situations and does not encourage students so that students can connect the material in everyday life. In relation to the problems presented in science learning, so far it tends to be oriented towards academic problems which are closed in nature, rarely related to the context. Likewise, in learning activities designed by the teacher, it has not emphasized the skills of students to argue using reasoning so that students have not been able to express their ideas or ideas, either orally or in writing. By not being trained students to express 
their ideas or ideas, it results in the development of ideas that students have. This event will cause low learning outcomes in students.

In relation to classroom learning, there are four pillars used as guidelines, namely learning to know, learning to do, learning to be, and learning to be together. to live together) Fatirul (2020). Therefore, the learning process should not position students as lecture listeners like filling empty bottles with knowledge. In the Competency Based curriculum developed by the Indonesian Ministry of National Education, one of the objectives is stated: students gain experience in the application of scientific methods through experiments or experiments, where students test hypotheses by designing experiments through the installation of instruments, collection, processing and interpretation of data, and communicating the experimental results orally and in writing (Ministry of National Education, 2003). From this goal, it is reflected that learning is no longer just relying on lectures, but rather on developing competencies, especially competency in science process skills. One of the learning innovations is implementing a learning model oriented to Group Investigation and Inquiry. This study aims to determine the differences in learning outcomes shown by students who learn with the group investigation method and the inquiry method, to find out the differences in learning outcomes shown by students between groups of students who have Visual, Auditorial and Kinesthetic learning styles, and to determine the interaction between the methods. and learning styles on student learning outcomes

\section{Group InVeStigation Learning Methods}

Investigation is a learning activity that gives students the possibility to develop understanding through various activities. Learning activities start with the problems given by the teacher, while subsequent learning activities tend to be open, meaning they are not structured, which in their implementation efers to various investigative theories. According to Bruce R. Joyce (2015) this model is highly adaptable and comprehensive combining the academic objectives of investigation, social integration and social learning processes, and can be used in all fields of study, at all age levels. According to Height, he explained that investigation is related to observing activities in detail and systematically assessing them. So an investigation is the process of an investigation carried out by a person, and then that person communicates the results of his acquisition, can compare it with the acquisition of other people, because in an investigation one or more results can be obtained. In class activities that develop class discussions, the various possible answers have implications for various alternative answers and arguments based on student experiences. The result is that students 'answers are not always right or even wrong because the preconceptions that underlie students' thinking are incorrect.

However, from these errors, the communication developed can provide direction for students' awareness of their mistakes, especially where the source of the error occurs. They will learn from their own mistakes by asking why other people get answers that are different from their answers. With an attitude of openness that must be developed in this investigative attitude, students learn not only to find the truth about the answer to the problem, but also to find the truth path using their own common sense and mental activities.

There is a difference between investigating and solving problems. Problem solving is a convergent activity where students must learn to find solutions. Meanwhile, investigation is a divergent activity in which students are given more opportunities to think about, develop, investigate interesting things that disturb their curiosity. It could be that person $\mathrm{A}$ is interested in part $\mathrm{X}$ to be investigated and person B is interested in other parts. Besides that, person A only investigates the surface, while person B with excellent thinking skills investigates these things in depth and in detail. For this 
reason, investigation is called an open and unlimited activity, because this activity depends on students' interests and differences in students' thinking abilities which of course are very different. Group discussions and class discussions are very important in order to provide the experience of expressing and explaining everything they think and opening up to what their friends think. A good experience like this will motivate students to learn and want to investigate (investigate) further. The experience of working together in many ways is in accordance with the spirit of mutual cooperation that has long developed in this beloved earth of Indonesia. This needs to always be developed by training it to students. In this investigation, students are required to be more active in developing their attitudes and knowledge about physics in accordance with their respective abilities so as to result in more meaningful learning outcomes for students. Between investigation and problem solving, in reality there is almost no difference, it's just that in investigations, the problems and solutions are usually relatively broader and more open, also the level of difficulty is usually higher, which is more familiarly known as "more open ended". Problem solving often appears as a convergent activity, that is, students have definite goals and the problem is to find a way to solve the problem, however in looking for problem solving it is often necessary to do investigations. Thus, problem solving and investigation should be integrated in the learning approach and not a separate part.

Investigation makes students to learn more actively and meaningfully, meaning that students are invited to think about certain problems and find their own way to solve them, therefore students will be trained to always use the knowledge skills they have, so that the knowledge and skills of students' learning experiences will be embedded for a long period of time. Long

The phases that must be taken in the investigative approach are: Reading phase, Problem solving phase, Answering phase and communicating answers. The role of the teacher in learning with an investigative approach is to provide clear information and instructions, provide guidance as needed by exploring student knowledge that supports problem solving (not showing how to solve it), providing encouragement so that students are more motivated such as preparing the facilities needed by students and lead the discussion to the final conclusion.

\section{INQUIRY LEARNING METHODS}

There are several definitions of the learning model. Bruce R. oyce (2015) argues that the learning model is a plan that is used as a guide for implementing the learning process in the classroom. This means that the learning model is a systematic step to organize student learning experiences to achieve certain goals in the learning process. Inquiry is a form of learning to find solutions to problems critically, analytically, scientifically by using certain steps towards an accurate conclusion because it is supported by data..In inquiry learning is thick with discovery which contains a mental process in which students or individuals assimilate concepts and principles. This mental process includes: observing, classifying, measuring, describing, drawing conclusions. Whereas inquiry is an extension of the discovery process used in a more mature way. In addition to the discovery process, inquiry contains high-level mental processes, such as formulating problems, designing experiments, conducting experiments, collecting and analyzing data, drawing conclusions, having an objective, honest, curious, open attitude.. The mental process that is formed will basically produce researchers who are scientific. Nurhadi (2004) defines inquiry as a process that moves from the observation step to the understanding step. The observations which form the basis of the various questions raised

asked by students, answers to these questions are pursued and obtained through a cycle of making predictions, formulating hypotheses, developing methods of testing hypotheses, making further observations, creating theories and concept models based on data and knowledge. 
The inquiry model is a learning technique where in the teaching and learning process, students are expected to always be faced with a problem. The learning process mainly motivates students to investigate existing problems by using scientific methods and skills to find an explanation.The main purpose of this type of learning model is to encourage students to develop scientific discovery skills and it will be interesting if students are given activities to investigate a number of information in order to find solutions to the problems they face. Piaget said that the inquiry method is a method that prepares students to conduct their own experiments, ask questions, and find answers on their own, as well as relate one finding to other findings. And compare what he found with what other students found (Mulyasa, 2007: 108). Inquiry learning is encouraged for students to be actively involved, and teachers encourage students to have experiences and conduct their own experiments (Nurhadi, 2004).Dimyati (2002: 73) states that the main stresses of learning with inquiry strategies are: Development of individual thinking skills through research, Increasing the ability to practice research models and techniques, Exercising special intellectual skills, which are in accordance with certain branches of knowledge, and Finding things out. Dimyati said that inquiry is very useful so that students become more active in thinking.

When the inquiry model is applied, the benefits obtained by students will have the opportunity to express their ideas and ideas, so that they will be able to improve their ability to write scientific papers.In addition, with the model of inquiry students have begun to be taught to analyze and seek the truth of a problem being discussed, have been able to think systematically, have direction and have clear goals, in addition to being able to think inductively, deductively, and rationally so that this will cause students have the ability in good formal reasoning.

The Ministry of National Education (2003: 2) explains that through the inquiry model it is hoped that the teacher can create challenging learning so that it creates an interaction between the ideas previously believed by students with new evidence to achieve new, more scientific understanding through the process of exploring or testing new ideas. This teaching model demands the formation of a cooperative class atmosphere but strict discipline. The teacher must guide the inquiry process and stimulate students to participate actively. The teacher must take care that the identification of facts does not become a central issue and should maintain strict discipline and inquiry. The teacher's job is to control the entire interaction process and explain the research procedures that must be followed. The philosophical characteristics of this model emphasize maximum personal development and focus on shaping the individual in the face of real life. The inquiry training model will have an instructional impact in the form of strategies in conducting creative research. Meanwhile, the accompanying impact obtained from this model is in the form of scientific process skills, creative spirit, independence or autonomy in learning, and tolerance for uncertainty.

Inquiry does not only develop intellectual abilities but all existing potential, including emotional and skill development. Gulo (2002: 93) states that the essence of inquiry is a process, which starts from formulating problems, developing hypotheses, gathering evidence, testing hypotheses, and drawing tentative conclusions.

\section{Learning Style}

Gaya belajar merupakan kombinasi dari bagaimana siswa menyerap, dan memproses informasi. Gaya belajar juga merupakan suatu pendekatan bagaimana siswa belajar dengan menutamakan proses, dan menguasai informasi yang sulit dan baru melalui persepsi yang mermacam-macam. Gaya belajar merupakan modalitas yang dapat diklasifikasikan menjadi tiga, yaitu gaya belajar visual, gaya belajar auditori dan gaya belajar kenestika (DePorter \& Hernacki, 2013).Basically, each individual has various kinds of learning styles, but there is one that is more dominant. Students always have a tendency to have one learning style and students also have a mixed learning style 
from other learning styles.Individuals have different learning styles. Students who can recognize their own learning style will be able to help understand the material provided by the teacher so that they can easily process the material well.If it is easy to process material and easy to remember, it is easy to take exams so that learning achievement increases.

A person in learning ideally not only depends on one way or one learning style but can combine several or all learning styles. This is because it is hoped that all of our organs can work actively and in balance. The information obtained can enter and be stored in the brain properly. Then if needed at any time the information can be removed from memory as well. It can be said that a person has good memory skills. The fact is that many people or students tend to only have one learning style in the learning process. This makes the existing information less well received and stored in the brain. This is because not all organs of the body work actively and do not work in balance so that certain materials and when one of the organs of the body is disturbed cannot carry out the learning process properly. For example, for sports material, it is not only necessary to practice in the field but also to learn theory in the classroom. When the hand is sick, so you can't write, you can learn by watching and listening to the teacher's explanation in front of the class.

So this research will focus on learning styles as a modality according to DePorter, namely; Visual, Auditory and Kinesthetic, (DePorter, 2001: 113), which will then look for their respective correlation as a moderating variable on differences in the use of group infestigation methods and inquiry methods on learning outcomes.

Furthermore, according to DePorter, the characteristics of learning styles are as follows: Visual (Neat and orderly, Speaks quickly, Good long-term planner and organizer, Meticulous attention to details, Fast and diligent reader, Good spelling and can see words). actual words in their mind, Remembering what was seen, rather than heard, Remembering with visual associations, and Usually not being bothered by fuss). Auditorial (Talking to himself while working, Easily distracted by noise, Moving lips and saying writing in a book when reading, Speaking in a patterned rhythm, Usually a fluent speaker, Has a moderate speaking speed, Enjoys reading aloud and listening, Learning by listening and remember what was discussed, and Like to talk, discuss and explain something at length). Kinesthetic has the habit of speaking slowly, standing close when talking to people, always moving a lot, the way of learning is through practice, memorizing by walking and looking, always using fingers as a pointer when reading, uses a lot of gestures, can't sit still for a long time, speaks slow, can be poorly written, and always does everything.

\section{RESEARCH METHODS}

This research is a quasi-experimental research using a factorial design $(2 \times 3)$ which consists of 4 variables: 2 independent variables, 1 moderator variable and 1 dependent variable. The independent variable is the group investigation method and the inquiry method, the moderator variable is learning style and the dependent variable is learning outcomes (Tuckman, 1999).

This design was chosen because the experiment was carried out in certain classes in existing classes. In determining the subject for the experimental group and control group, it is not possible to change the existing class.Thus randomization cannot be done. In determining the experimental group and the control group, it was done randomly from the existing classes.

The factorial design in the study is described as follows. Factorial Research Design $(2 \times 3)$ (Sugiyono, 2010). 
Table 1: Research Design

\begin{tabular}{|l|l|l|}
\hline $\begin{array}{l}\text { Method } \\
\text { Learning Style }\end{array}$ & $\begin{array}{l}\text { Investigation Group } \\
(\mathrm{A})\end{array}$ & $\begin{array}{l}\text { Inquiry Group } \\
(\mathrm{B})\end{array}$ \\
\hline Visual (1) & $\mathbf{Y}(\mathbf{A , 1})$ & $\mathbf{Y}(\mathbf{B , 1})$ \\
\hline Auditori (2) & $\mathbf{Y}(\mathbf{A , 2})$ & $\mathbf{Y}(\mathbf{B , 2})$ \\
\hline Kinestetik (3) & $\mathbf{Y}(\mathbf{A , 3})$ & $\mathbf{Y}(\mathbf{B}, \mathbf{3})$ \\
\hline
\end{tabular}

The population of this study involved State Senior High Schools which involved 2 different schools. Amount by sum total. Sampling was done by random selection. The selection was based on a homogeneous group by taking into account the chemical, audio, and audio visual learning styles with a total sample of 112 students. In grouping the experiment was divided into 2 groups, including groups using group investigations with a total of 58 students and groups using the use of the inquiry method with a total of 54 students.

The method of data collection was carried out in 2 forms, including: to collect data on student learning styles used questionnaires, and to determine student achievement by using tests.

Data analysis to determine the effect of 2 independent variables, (Group Investigation Method and Inquiry Method) and moderator variable (Learning Style) on learning achievement using Two Way Anova analysis. Before conducting the experiment, the homogeneity and normality test was carried out and the item validity test (pre test and post test) used the Contain of Validity technique.

\section{RESUlTS AND DisCUSSION}

\subsection{Sample Homogeneity Test}

The sample homogeneity test in the study will use Fisher's Levene Test. The rules that apply in this sample homogeneity test are:

If the significance $(\mathrm{sig}) \leq 0.05$, then the two samples (group investigation and inquiry learning methods group) are declared not homogeneous

If the significance (sig)> 0.05 , then the two samples (group investigation and inquiry learning methods group) are declared homogeneous

From the results of the homogeneity test calculations are shown in table 2 below:

Table 2: Sample Homogeneity Test

Independent Samples Test

$\begin{array}{ccc} & \begin{array}{c}\text { Pre-test } \\ \text { Equal variances } \\ \text { assumed }\end{array} \\ \text { Levene's Tes for } & \text { F } & .101 \\ \text { Equality of Variances } & \text { Sig. } & .752\end{array}$

From the results of Levene's test or Levene's test, it can be seen that the F value is 0.101 with a significance (sig) of 0.752 . Because sig is $0.752>0.05$, the two sample groups (group investigation and inquiry) are stated to have homogeneous variants. 


\subsection{Normality Test}

\section{To test for normality use the formula $\mathrm{Z}$ or $\mathrm{Z}$-test from Kolmogorov-Smirnov, as follows:}

If the significance $(\mathrm{sig}) \leq 0.05$, then the data is declared to have an abnormal distribution

If the significance $(\mathrm{sig})>0.05$, then the data is declared to have a normal distribution

From the calculation results, the results are shown in table 3 below:

Table 3: Data Normality Test

One-Sample Kolmogorov-Smirnov Test

\begin{tabular}{|c|c|c|c|}
\hline & & $\begin{array}{l}\text { Investigation } \\
\text { Group }\end{array}$ & $\begin{array}{l}\text { Inquiry } \\
\text { Group }\end{array}$ \\
\hline \multicolumn{2}{|l|}{$\mathrm{N}$} & 54 & 54 \\
\hline \multicolumn{2}{|l|}{ Normal Parameters } & 68.52 & 77.41 \\
\hline & Mean & 8.447 & 6.350 \\
\hline Kolmogororov-Smirnov $\mathrm{Z}^{\mathrm{a}, \mathrm{b}}$ & Std. Deviation & 1.328 & 1.165 \\
\hline Asymp. Sig. (2-tailed) & & .059 & .133 \\
\hline
\end{tabular}

The table for the normality test of student learning outcomes data from the investigative learning method group and the inquiry learning method group, with a total sample size of 54 each, shows: The average learning outcome of the group investigative learning method group is 68.52 with a standard deviation of 8.447

2. The average learning outcome of the inquiry learning method group was 77.41 with a standard deviation of 6.350

Table 3 also shows:

The Z-value for the group investigative learning method group is 1.328 with a significance (sig) of 0.059 . Because the sig is $0.059>0.05$, the data distribution for the group investigative learning method group is declared normal.

The Z-value for the inquiry learning method group is 1.165 with a significance (sig) of 0.133 . Because sig is $0.133>0.05$, the data distribution for the inquiry learning method group is normal.

\subsection{Hypothesis Test}

By ensuring that the sample has a homogeneous sample distribution tested from the pre-test result data and the data has a normal distribution from the post-test result data, then it can then be forwarded to parametric hypothesis testing, in this case the relevant one is Two Way Anova, as seen in the table below.

The rules that apply in testing the hypothesis are:

If the significance $(\mathrm{sig})>0.05$, then there is no difference in learning outcomes between the investigative group and the inquiry group 
International Journal on Information Theory (IJIT) Vol.10, No.1/2/3, July 2021

If the significance $(\mathrm{sig})<0.05$, then there is a difference in learning outcomes between the investigative group and the inquiry group.

Table 4: Two Way Anova Analysis

Tests of Between-Subjects Effects

Dependent Variable: Learning Outcomes

$\begin{array}{llllll}\text { Source } & \begin{array}{l}\text { Type III Sum of } \\ \text { Squares }\end{array} & \text { df } & \begin{array}{l}\text { Mean } \\ \text { Square }\end{array} & \text { F } & \text { Sig. } \\ \text { Corrected Model } & 4028.325 \mathrm{a} & 4 & & & \\ \text { Intercept } & 178376.241 & 1 & 1007.081 & 24.681 & .000 \\ \text { Learning Methods } & 1277.583 & 1 & 178376.241 & 4371.471 & .000 \\ \text { Learning Style } & 1723.282 & 2 & 1277.583 & 31.310 & .000 \\ \text { Learning Style of Moderation } & 57.145 & 1 & 861.641 & 21.116 & .000 \\ \text { Error } & 4366.095 & 107 & 57.145 & 1.400 & .239 \\ \text { Total } & 600725.000 & 112 & 40.805 & & \\ \text { Corrected Total } & 8394.429 & 111 & & & \end{array}$

$\mathrm{R}$ Squared $=.480$ (Adjusted R Squred $=.460$

The test table between subject effects above shows:

The $\mathrm{F}$ value for the corrected model (learning methods and learning styles) is 24.681 with a significance (sig) of 0.000 . Because sig $0.000<0.05$, it is concluded that the interaction between learning methods and learning styles has an influence on student learning outcomes

The $\mathrm{F}$ value for the intercept, which is the influence of variables outside the learning method and learning style, is 4371.471 with a significance (sig) of 0.000 . Because the sig is $0.000<0.05$, the inference is that there is an influence outside the variables of learning methods and learning styles on student learning outcomes.

The $\mathrm{F}$ value for the learning method variable is 31.310 with a significance (sig) of 0.000 . Because the sig is $0.000<0.05$, the inference is that there are differences in student physics learning outcomes on the subject of Impulse Momentum in terms of the learning method between group investigation and inquiry.

The $\mathrm{F}$ value for the learning style variable is 21,116 with a significance (sig) of 0,000 . Because the sig is $0.000<0.05$, the inference is that there are differences in student physics learning outcomes on the subject of Impulse Momentum in terms of student learning styles between kinesthetic, auditory and visual learning styles.

The $\mathrm{F}$ value for the learning style variable as moderation is 1,400 with a significance (sig) of 0.239 . Because the sig is $0.239>0.05$, the inference is that there is no difference in student physics learning outcomes on the subject of Impulse Momentum in terms of learning styles as moderation.

The results of the data analysis showed that the learning style variable did not moderate the learning method so that there was no interaction between learning methods and learning styles on student learning outcomes.

In detail, the interactions between the two variables with various combinations can be seen in the table below. 
International Journal on Information Theory (IJIT) Vol.10, No.1/2/3, July 2021

Table 5: Advanced Two Way Anova Analysis

Learning Outcomes*Learning Style Group

Dependent Variable: Learning Outcomes

\begin{tabular}{|c|c|c|c|c|c|}
\hline \multirow{2}{*}{$\begin{array}{l}\text { Learning } \\
\text { Methods }\end{array}$} & \multirow{2}{*}{ Learning Style Group } & \multirow{2}{*}{ Mean } & \multirow{2}{*}{ Std. Error } & \multicolumn{2}{|c|}{$\begin{array}{l}95 \% \text { Confidence } \\
\text { Interval }\end{array}$} \\
\hline & & & & $\begin{array}{l}\text { Lower } \\
\text { Bound }\end{array}$ & $\begin{array}{l}\text { Upper } \\
\text { Bound }\end{array}$ \\
\hline \multirow{4}{*}{ Investigation } & Kinestika & 56.667 & 3.688 & 49.356 & 63.978 \\
\hline & Auditori & 66.316 & 1.036 & 64.262 & 68.370 \\
\hline & Visual & 75.000 & 1.549 & 71.929 & 78.071 \\
\hline & Kinestika & $\mathrm{a}$ & & & \\
\hline \multirow[t]{2}{*}{ Inquiry } & Auditori & 75.000 & 1.147 & 72.726 & 77.274 \\
\hline & Visual & 80.652 & 1.332 & 78.012 & 83.293 \\
\hline
\end{tabular}

The combination of these factor levels was not observed, so the appropriate the marginal population mean cannot be estimated.

The table above shows:

Learning outcomes from the effect of investigative learning methods moderated by kinesthetic learning styles are 56.667.

Learning outcomes from the effect of investigative learning methods moderated by auditory learning styles are 66.316.

Learning outcomes from the influence of investigative learning methods moderated by visual learning styles are 75,000.

Learning outcomes from the effect of the inquiry learning method moderated by the kinesthetic learning style cannot be estimated, because there is no combination between the two in the experiment.

Learning outcomes from the influence of inquiry learning methods moderated by auditory learning styles are 75,000 .

Learning outcomes from the influence of inquiry learning methods moderated by visual learning styles are 80,652 .

From the description above, it can be seen that the most optimal learning outcomes are obtained from the effect of a combination of inquiry learning methods moderated by visual learning styles, so empirically this kind of phenomenon is a recommendation for the development of student learning outcomes that are developed at a later date. 
International Journal on Information Theory (IJIT) Vol.10, No.1/2/3, July 2021

Table 6: Anova test with the Scheffee method

Multiple Comparisons

Dependent Variable: Learning Outcomes

Scheffe

\begin{tabular}{lllllll} 
(I) & (J) & Mean & & \multicolumn{3}{c}{$95 \%$ Confidence } \\
Learning Style & Learning Style & Difference & Std. & Sig. & $\begin{array}{l}\text { Interval } \\
\text { Lower }\end{array}$ & Upper \\
Group & Group & $(\mathrm{I}-\mathrm{J})$ & & & & $\begin{array}{l}\text { Bound } \\
\text { Bound }\end{array}$ \\
Kinestika & Auditori & $-13.55^{*}$ & 3.767 & .003 & 122.90 & -4.20 \\
& Visual & $-21.58^{*}$ & 3.824 & .000 & -31.08 & -12.09 \\
Auditori & Kinestika & $13.55^{*}$ & 3.767 & .002 & 4.20 & 22.90 \\
& Visual & $-8.03^{*}$ & 1.269 & .000 & -11.18 & -4.88 \\
Visual & Kinestika & $21.58^{*}$ & 3.824 & .000 & 12.09 & 31.08 \\
& Auditori & $8.03^{*}$ & 1.269 & .000 & 4.88 & 11.18
\end{tabular}

Based on observed means

* The mean difference is significant at the, 05 level.

Table 6 shows:

The mean difference between auditory and kinesthetic learning styles is 13.55 with a significance ( $\mathrm{sig}$ ) of 0.002 . Because the sig is $0.002<0.05$, the inference is that there are differences in learning outcomes between students who have an auditory learning style and students who have a kinesthetic learning style.

The mean difference between visual and kinesthetic learning styles is 21.58 with a significance (sig) of 0.000 . Because sig is $0.000<0.05$, the inference is that there are differences in learning outcomes between students who have a visual learning style and students who have a kinesthetic learning style.

The mean difference between visual and auditory learning styles is 8.03 with a significance (sig) of 0.000 . Because sig is $0.000<0.05$, the inference is that there are differences in learning outcomes between students who have visual learning styles and students who have auditory learning styles. The description above describes that between the three learning styles head to head each shows a difference in learning outcomes. The learning style that is considered the best in improving learning outcomes can be seen in Scheffe's Advanced Anova test below.

Table 7: Anova test with the Multiple Region Scheffee method

Sceffe a,b,c

Learning Outcomes

$\begin{array}{lllll}\text { Learning Style Group } & \mathrm{N} & \begin{array}{l}\text { Subset } \\ 1\end{array} & 2 & 3 \\ \text { Kinestika } & & 56.67 & & \\ \text { Auditori } & 3 & & 70.22 & 78.25 \\ \text { Visual } & 69 & & & 1.000 \\ \text { Sig. } & 40 & 1.000 & 1.000 & \end{array}$

Means for groups in homogeneous subsets are displayed.

Based on Type III Sum of Squares

The error term is Mean Square(Error) $=40,805$.

Uses Harmonic Mean Sample Size $=8,047$.

The group sizes are unequal. The harmonic mean of the group

sizes is used. Type I error levels are not guaranteed.

Alpha $=, 05$. 
Table 7 can be explained that:

Subset 1 is occupied by kinesthetic learning styles with a mean of 56.67, which means that learning outcomes that have a kinesthetic learning style are significantly different from learning outcomes that have other learning styles, which are in different subsets.

Subset 2 is occupied by auditory learning styles with a mean of 70.22, which means that learning outcomes that have auditory learning styles are significantly different from learning outcomes that have other learning styles, which are in different subsets.

Subset 3 is occupied by visual learning styles with a mean of 78.25 , which means that learning outcomes that have visual learning styles are significantly different from those of students who have other learning styles, who are in different subsets.

The conclusion from the description above is that optimal learning outcomes are obtained from a visual learning style because it has the highest mean (because it occupies the last subset). Comparison of Learning Outcomes According to Learning Styles Conclusively it appears that learning outcomes using visual learning styles are able to provide the best results, because they can produce the highest level of learning outcomes, when compared with learning outcomes using kinesthetic learning styles and auditory learning styles.

\section{Completeness LeVeL}

The condition for scoring the level of completeness is to give a score of 1 on the correct answer and a score of 0 on the wrong answer. If students get a minimum score of 75 , this means that there is an increase in learning outcomes and if students get a score of less than 75 then there is no increase in learning outcomes, or it can be said that learning has not been completed. The results of the frequency distribution of student learning completeness can be explained as follows:

Table 8: Students' Complete Learning Level

Learning Outcomes

$\begin{array}{llll} & & \text { Frequncy } & \text { Percent } \\ \text { Valid } & \text { Not Complate } & 55 & 49.11 \\ & \text { Complate } & 57 & 50.89 \\ & \text { Total } & 112 & 100.00\end{array}$

Table 8 above shows that the majority of respondents (50.89 percent) experienced mastery in learning, meaning that 50.89 percent of respondents had achieved a minimum learning outcome score of 75 .

\section{DisCUSSION}

From the results of the analysis, it is shown that learning using the method of investigation in groups provides prominent results from the use of the inquiry method, as evidenced by several previous studies that have been carried out such as research by Lawrence W. Sherman, (1989) that the investigation group has high achievement, Nor Chotimah. Dwi Rukmini (2017) concluded that there is a significant difference between STAD and GI techniques for teaching reading comprehension to highly motivated students. Therefore, the STAD technique is recommended to be applied in reading comprehension learning, Hendrik Pratama at.al. (2017) concluded that this learning was designed by starting, grouping, planning, presenting, organizing, investigating, 
evaluating, the final stage. The integration of WhatsApp with the group investigation method can lead to positive communication between students and lecturers. Discussions in this learning are carried out well, student knowledge can appear in groups and information can be spread evenly and quickly, Yael Sharan (2013) states that this model is very suitable for today's intercultural classes because the content of questions is determined by diversity of interests, experiences and student knowledge, Ivy Geok Chin at.al. (2010) stated that students who excel have much higher academic achievement than students who have low achievement. The group investigation method did not have a different effect on the 2 high and low achievement groups. This indicates that the learning method which is packaged with the group investigation method further enhances students' appreciation in increasing their learning achievement.

Another thing with the differences in learning styles that students have, there is research that supports differences in learning styles there are also those that support. Previous research found that as has been done, Abdul Rahman, Ansari Ahmar (2017) found that visual learning styles and auditory learning styles were dominated by women; and there is no relationship between learning style variables, gender and interaction of learning styles with gender on learning achievement, Gary Cheng Juliana Chau (2014) states that student learning styles are significantly associated with online participation and online participation in networked learning and material development significantly. related to learning achievement and subject satisfaction, Chei-Chang Chiou, at.al. (2017) concluded that the computer-assisted concept mapping technique must be in accordance with the learning styles of students. The suitability between learning styles and learning techniques will further improve learning achievement, Yu-Hsin Cheng, at.al. (2012) that students who have convergent learning styles in traditional learning are significantly better than students who have the other three learning styles.However, students who are exposed to the same three other learning styles perform better when faced with a multimedia computer-assisted teaching model, Stephen Rayner, Richard Riding (2010) that an overview of contemporary styles can contribute to the rationalization of theory and facilitate the adoption of a larger learning style. in educational practice, KH Wang at.al. (2006) stated that the performance of the FAM - WATA group is higher than the N-WATA and PPT groups. Students who have a 'Diverger' learning style are more likely to follow, compared to, 'Assimilator', 'Accommodator', and 'Converger' respectively.Finally, the students of the FAM-WATA group were satisfied with the six FAM-WATA strategies. From research that supports differences in learning styles, several studies show unsupportive results for differences in learning styles, such as research conducted by Yilmaz-Soylu at.al. (2009) concluded that this type of learning style is not significantly effective on learning achievement with different learning environments. Arsyad's research (2018) concludes that the use of conventional media does not have a significant effect on student achievement, both students who have visual and auditory styles.The research findings show that teachers pay more attention to the use of multimedia in their classes and consider students' learning styles.

Several studies on inquiry learning models that are applied in an effort to improve formal reasoning skills and improve students' writing abilities, including:

\section{CONClusion}

Based on the descriptions that have been presented in the previous chapters, the following conclusions can be drawn:

There is a difference in learning outcomes shown by students who study with the group investigation method with the accepted inquiry method with a significance level of 0.000 (less than $\alpha$ ). So that the learning outcomes using the inquiry learning method are higher than the learning outcomes using the group investigation learning method. 
International Journal on Information Theory (IJIT) Vol.10, No.1/2/3, July 2021

There are differences in student learning outcomes with visual, auditory, and kinesthetic learning styles with a significance level of 0.000 . The results of the ANOVA calculation (Scheffee Dual Region method), the highest mean are students who have a visual learning style of 78.25 , therefore visual learning style is a learning style that provides optimal learning outcomes because it has the highest mean. compared to the average auditory and kinesthetic learning styles

There is no interaction between methods and learning styles on student learning outcomes, so the hypothesis which says "There is an interaction between methods and learning styles on student learning outcomes" is rejected because the significance level is 0.239 (more than $\alpha$ ), possibly because:

Incorrect test made

Inhomogeneous experimental class samples

A measuring instrument that cannot measure what it measures

It is hoped that in the future, a teacher in carrying out the learning process always invites and gives activities to his students to carry out investigations to get an understanding of the material that has been given by the teacher can be understood in accordance with what the students expect as the satisfaction of their curiosity. By carrying out this investigative method, it will bring students to the application of the theories obtained according to what is happening in the field as a form of application or application in the real world.

\section{ACKNOWLEDGEMENTS}

Thank you to the chairman of the foundation and the Chancellor of the University of PGRI Adi Buana Surabaya who have facilitated this research. All validation experts who have provided input on the products developed, colleagues and lecturers who help in the learning process, as well as to students who have supported them as objects in this research.

\section{REFRERENCES}

[1] Abdul Rahman, Ansari Ahmar, 2017. Relationship between Learning Styles and Learning Achievement in Mathematics Based on Genders, World Transactions on Engineering and Technology Education Journal, Vol. 15, No.1, https://papers.ssrn.com/sol3/papers.cfm?abstract_id=2940942. Accessed: August 18, 2020

[2] Bruce R. Joyce, Marsha Weil, Emily Calhoun, 2015. Models of Teaching, 9th Edition,, Booksend Laboratories,, ETR Associates,, The Phoenix Alliance, https://www.pearson.com/us/highereducation/program /Joyce-Models-of-Teaching-9th-Edition/PGM243928.html

[3] Arsyad Abd Gani, Nurdin Ibrahim, 2018. Multimedia use and learning styles on learning achievement in social studies, Social Sciences and Humanities International Journal, Vol. 2, No. 2, http://www.sciencescholar.us/journal/index.php/ijssh/article/view/163. Accessed: September 5, 2020

[4] Chei-Chang Chiou, Li-Tze Lee, Li-Chu Tien, Yu-Min Wang, 2017. Analyzing the Effects of various Concept Mapping Techniques on Learning Achievement under different Learning Styles, EURASIA J Math Sci Tech Ed, Volume 13 Issue 7, pp. 3687-3708, https://www.ejmste.com/article/analyzing-theeffects-of-various-concept-mapping-techniques-on-learning-achievement-under-different-4851, Accessed: September 5, 2020

[5] Ministry of National Education. 2003. Special Guidelines for Syllabus Development and Assessment of Physics Subjects. Jakarta: Depdiknas.

[6] DePorter, B.M. Rerdor, S. Nourie. 2001. Quantum Teaching. Translator Ary Nilandri. Bandung:

[7] DePorter, Bobbi and Hernacki, Mike. 2013. Quantum Learning: Getting used to learning, comfortable and fun. Bandung: Kaifa Learning. 
International Journal on Information Theory (IJIT) Vol.10, No.1/2/3, July 2021

[8] Dimyati, and Mudjiono. 2002. Learning And Learning. Jakarta: Project for Guidance and Quality Improvement of Education Personnel of the Ministry of Education and Culture.

[9] Fatirul, Noor, Achmad, 2020. Become a Professional Teacher and Lecturer, Publisher: Pena Persada, Purwokerto.

[10] Gary Cheng Juliana Chau, 2014. Exploring the relationships between learning styles, online participation, learning achievement and course satisfaction: An empirical study of a blended learning course, British Journal of Educational Technology, Vol. 47, Issue 2, pp. 257-278, https://berajournals.onlinelibrary.wiley.com/doi/abs/10.1111/bjet.12243

[11] Gulo, W. 2002. Teaching and Learning Strategies. Jakarta: PT Gramedia Widiasarana Indonesia.

[12] Hendrik Pratama, Sulistyaning Kartikawati, 2017. The Effect of WhatsApp Messenger As Mobile Learning Integrated with Group Investigation Method of Learning Achievement, International Journal of Science and Applied Science: Conference Series Int. J. Sci. Appl. Sci .: Conf. Ser., Vol. 2 No. 1, https://jurnal.uns.ac.id/ijsascs/article/view/16702/13486, Accessed: August 20, 2020

[13] Higbee Kenneth L, 2003, Your Memory, Semarang: Dahara Prize. http://www.google.co.id (accessed March 21, 2010) .

[14] Ivy Geok Chin Tan, Shlomo Sharan \& Christine Kim Eng Lee, 2010. Group Investigation Effects on Achievement, Motivation, and Perceptions of Students in Singapore, The International of WEducational Research, Volume 100 no. 3, Pages 142-154, https://doi.org/10.3200/JOER.100.3.142154, Accessed: October 21, 2020

[15] K.H. Wang T.H. Wang W. L. Wang S. C. Huang, 2006. Learning styles and formative assessment strategy: enhancing student achievement in Web-based learning, Journal of Computer Assisted $\begin{array}{llll}\text { Learning, } & 22, & \text { pp. }\end{array}$ http://citeseerx.ist.psu.edu/viewdoc/download?doi=10.1.1.495.6659\&rep=rep1\&type=pdf

[16] Lawrence W. Sherman, 1989. A comparative study of cooperative and competitive achievement in two secondary biology classrooms: The group investigation model versus an individually competitive goal $\begin{array}{lllllll}\text { structure, } & \text { JRST } & \text { Vol. } & 6 & \text { Issue } & 1 & \text { page: }\end{array}$ https://onlinelibrary.wiley.com/doi/abs/10.1002/tea.3660260106, Accessed: july 11, 2020

[17] Mulyasa, E. 2007. Becoming a Professional Teacher Creating Creative and Fun Learning, Bandung: Rosdakarya.

[18] Nor Chotimah, Dwi Rukmini, 2017. The Effectiveness of Student Team Achievement Division (STAD) and Group Investigation (GI) Techniques to Students With High and Low Motivation English Education Journal, (7) 1, https://eric.ed.gov/?id=ED288853, Accessed: September 5, 2020

[19] Nurhadi, et al. 2004. Contextual Learning and Its Application in the KBK. Malang: State University of Malang.

[20] Stephen Rayner \& Richard Riding, 2010. Towards a Categorisation of Cognitive Styles and Learning Styles, An International Journal of Experimental Educational Psychology, Volume 17, Issue 1-2, Pages 5-27, https://doi.org/10.1080/0144341970170101, Accessed: September 5, 2020

[21] Sugiyono, 2010. Statistics for Research, Publisher: Alfabeta, Bandung.

[22] Tuckman, Bruce W., 1999. Conducting Education Research, Printed in The United States of Amarica.

[23] Winkel WS, S.J. M, 1991, Teaching Psychology, Jogiakarta: Media Abadi.

[24] Yael Sharan, 2013. Expanding Cooperative Learning Through Group Investigation.

[25] Yilmaz-Soylu, Meryem; Akkoyunlu, Buket, 2009. The Effect of Learning Styles on Achievement in Different Learning Environments, Journal of Educational Technology - TOJET, v8 n4 p43-50, https://eric.ed.gov/?id=EJ859496

[26] Yu-Hsin Cheng, Ju-Tzu Ceng, Deng-Jyi Chen, 2012. The Effect of Multimedia Computer Assisted Instruction and Learning Style on Learning Achievement, WSEAS Transctions on Information Science and Applications, Issue 1, Volume 9, pp. 24-35, http://www.wseas.us/journal/pdf/information/2012/54286.pdf, Accessed: September 5, 2020 